\title{
A Case of Ulcerative Colitis Patient with Colonic Stenosis and Enterocutaneous Fistula
}

\author{
Seong Yeon Jeong, You Sun Kim, Kyeong Sam Ok, Sun Ok Kwon, Jin Nam Kim, Jeong Seop Moon, \\ Yun Kyung Kang ${ }^{1}$, Seong Woo Hong ${ }^{2}$ \\ Departments of Internal Medicine, Pathologyl' and General Surgery², Seoul Paik Hospital, Inje University College of Medicine, Seoul, Korea
}

Ulcerative colitis (UC) is one of the chronic inflammatory bowel diseases (IBD), characterized by a diffuse mucosal inflammation limited to the colon. Complications of UC include stricture, colorectal cancer, and toxic colitis. UC patients rarely present with a stenosis or fistula, and strictures develop in less than $5 \%$ of patients with UC. We present a patient with UC, accompanied by unusual complications that involved not only a stricture but also a fistula and abscess. A 49-year-old female was presented with a left flank pain and fever that had begun two weeks before admission. She had received a diagnosis of UC 20 years ago and had it treated for 2 years in a local hospital. However, she arbitrarily stopped visiting the hospital and relied on home remedies. An abdominopelvic CT scan revealed luminal narrowing and extra-peritoneal fistula formation in the descending colon. Fistula was connected with a subcutaneous abscess in the left flank. She had undergone total colectomy and ileo-anal anastomosis. On the pathologic exam, the long standing UC with severe stenosis was observed without malignant change. It cannot be emphasized enough that a correct therapeutic approach and an appropriate follow-up schedule are very important for patients with UC. (Intest Res 2012;10:388-391)

Key Words: Ulcerative Colitis; Stenosis; Fistula; Abscess

\section{서 론}

궤양성 대장염은 호전과 악화를 반복하는 만성 특발성 염증성 장 질환의 하나로 주로 대장을 침범한다. 주 증상으로는 혈성 설사와 대 변 급박감 및 복통 등이 있고 중증에선 전신 쇠약감, 식욕 부진, 발 열 등이 동반된다. 원인은 아직 불명확하지만 유전적 요인, 환경적 요 인, 면역학적 요인 등이 복합적으로 작용한다고 추정하고 있다. 궤양 성 대장염의 합병증으로는 독성 거대결장, 출혈, 대장암 등이 발생할 수 있다. 크론병의 경우 약 $40 \%$ 의 환자에서 장관의 협착이 동반되는 반면 궤양성 대장염은 점막 또는 점막하층에 병변이 국한되는 특징 의 질병으로, 비교적 드문 5-10\% 정도에서 협착이 발생한다. ${ }^{2}$ 우리나 라에서 궤양성 대장염의 장관 내 협착 및 이의 치료에 대한 보고는 매 우 드물다. 최근 Lee 등 ${ }^{3}$ 은 궤양성 대장염의 길이가 짧은 양성 협착 을 풍선 확장술을 이용해 성공적으로 치료하였음을 보고하였다. 하지

Received March 12, 2012. Revised April 25, 2012. Accepted May 2, 2012. Correspondence to You Sun Kim, Department of Internal Medicine, Seoul Paik Hospital, 85, Geo-dong 2-ga, Jung-gu, Seoul 100-032, Korea. Tel: +822-2270-0012, Fax: +82-2-2270-0579, E-mail: yousunk69@korea.com
만 국내 및 국외의 문헌을 확인하였으나 궤양성 대장염 환자에서 장 관 협착과 그에 동반된 누공 및 농양이 발생한 보고는 아직까지 없었 다. 저자들은 오랫동안 치료받지 않은 궤양성 대장염 환자에서 발생 한 대장의 협착과 그로 인하여 발생한 장피누공 및 농양을 경험하였 기에 보고한다.

증 례

49세 여자가 2주 전부터 발생한 왼쪽 옆구리 통증 및 발열을 주소 로 내원하였다. 20년 전 혈변과 설사로 타 병원에서 궤양성 대장염을 진단받고 스테로이드 복용을 포함하여 약 2년간 치료받았으나 스스 로 치료 중단 후 민간요법에 의지하여 지냈다. 환자의 종교는 '여호와 의 증인'이었고 음주와 흡연은 하지 않았다. 활력징후는 혈압 $130 / 80$ $\mathrm{mmHg}$, 맥박 110 회/분, 호흡 20 회/분, 체온 $38.1^{\circ} \mathrm{C}$ 였다. 급성 병색 을 보였고 결막은 창백하였으나, 황달은 없으며 흥부 및 심음 청진 시 이상 소견은 없었다. 복부 촉진 시 왼쪽 옆구리에서 압통 및 열감을 동 반한 종괴가 만져졌다. 내원 당시 말초 혈액검사에서 혈색소는 5.0 $\mathrm{g} / \mathrm{dL}$ 으로 감소되어 있었고 백혈구 수는 $16,100 / \mathrm{mm}^{3}, \mathrm{C}$-반응단백

(c) Copyright 2012. Korean Association for the Study of Intestinal Diseases. All rights reserved.

This is an Open Access article distributed under the terms of the Creative Commons Attribution Non-Commercial License (http://creativecommons.org/licenses/by-nc/3.0)

which permits unrestricted non-commercial use, distribution, and reproduction in any medium, provided the original work is properly cited. 

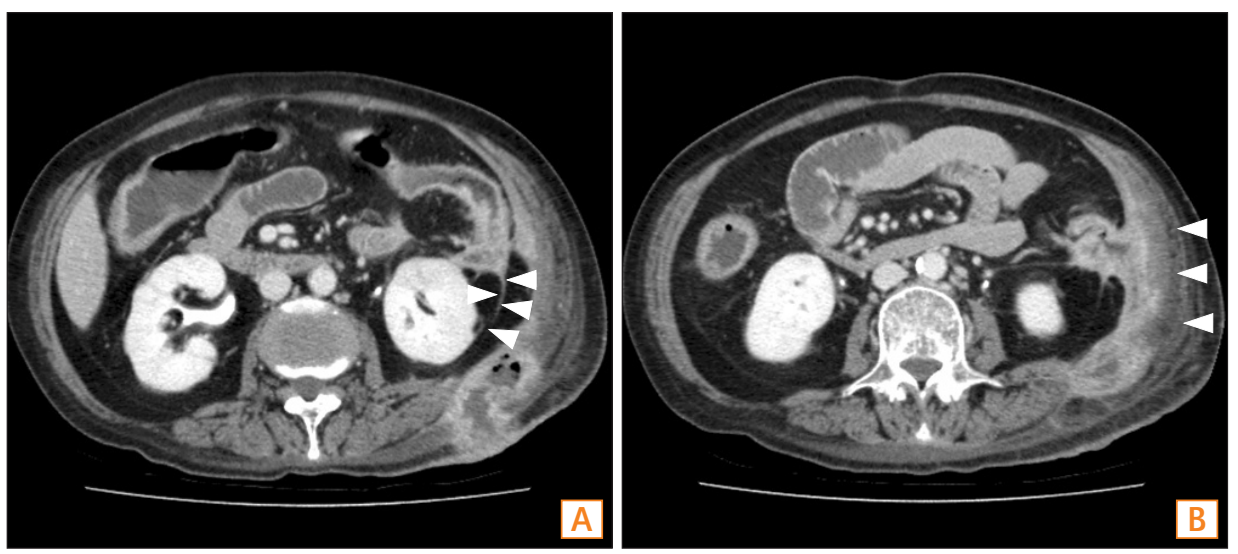

Fig. 1. Abdominopelvic computed tomography. It shows a continuous loss of haustral markings in the transverse colon. (A) Colon to skin fistula tract was noticed (white arrow heads). (B) Abscess is found in the left flank and back areas (white arrow heads).

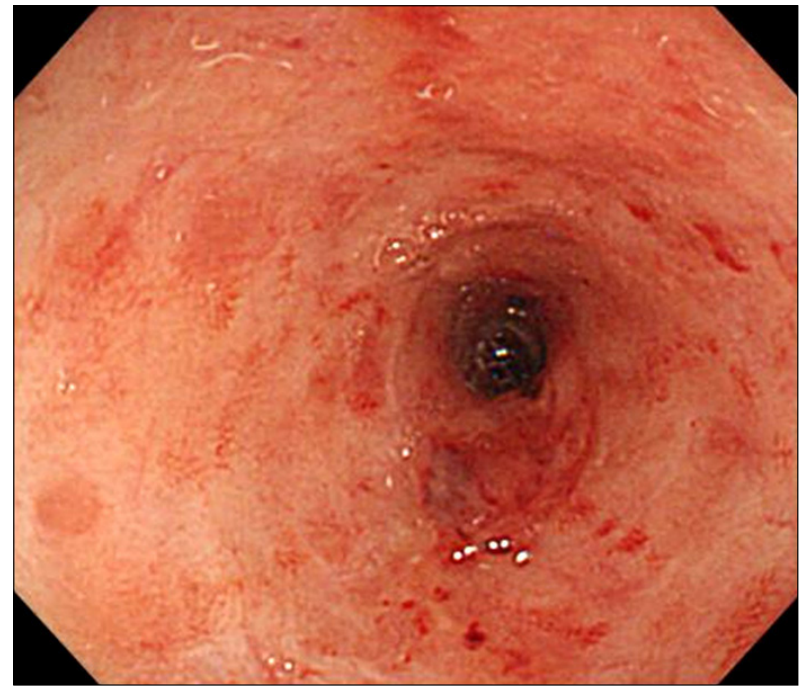

Fig. 2. Colonoscopic findings. It shows diffuse mucosal hemorrhage, whitish fibrotic mucosal change and severe stenosis in the descending colon.

$6.7 \mathrm{mg} / \mathrm{dL}, \mathrm{ESR} 70 \mathrm{~mm} / \mathrm{hr}$ 로 염증수치가 증가된 소견을 보였다. 혈액생화학검사에서 총단백 $5.61 \mathrm{~g} / \mathrm{dL}$, 알부민 $2.3 \mathrm{~g} / \mathrm{dL}$ 으로 감소 된 소견을 보였으며 그 밖의 다른 생화학검사 및 전해질 검사와 종양 표지자 검사는 정상이었다. 복부 전산화단층촬영에서 전 대장의 팽출 상(haustral marking)이 소실된 소견을 보였고 하행결장 내강의 심한 협착과 함께 누공이 관찰되었는데 누공은 피하의 농양과 연결되어 있 었다(Fig. 1). 농양 치료를 위해 경정맥을 통한 퀴놀론계 항생제와 메 트로니다졸 투여를 시작하였고 경피적 배농술을 시행하였다. 농양에 서 시행한 배양검사에서 Escherichia coli가 배양되었고 퀴놀론계 항 생제에 감수성이 확인되었다. 종교적인 이유로 수혈은 불가능하여 경 정맥 철분과 erythropoietin을 투여하였으며 경구 메살라진 복용을 시 작하였다. 3 주 후 혈색소는 $10 \mathrm{~g} / \mathrm{dL}$ 까지 상승하였고 추적 복부 전산 화단층촬영에서 농양은 소실된 소견을 보여 배농관을 제거하였다. 하 지만 샛길 소견이 여전히 관찰되고 대장 내강의 심한 협착 때문에 경 구 식사가 불가능하다고 판단되었다. 또한 환자의 전신 상태가 전대

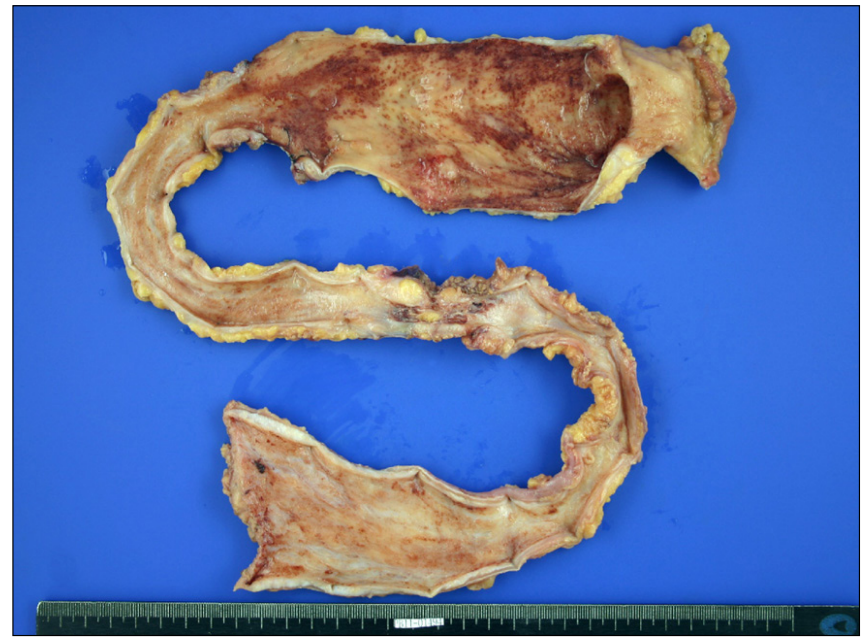

Fig. 3. The gross specimen. It shows significant shortening of the coIon, fibrosis and contraction in the descending colon.

장절제술을 시행받기에는 무리라고 판단되어 치료 시작 4 주 후 고식 적 횡행결장 창냄술(transverse colostomy)을 시행하였다. 횡행결장 창냄술 시행 후 항생제 치료를 중단할 수 있었고 경구 식사를 시작하 였으며 영양상태가 전반적으로 호전되었다.

수술 시행 2 주 뒤 병변의 범위와 중증도 평가를 위해 대장내시경 검사를 시행하였다. 결장루로 진입시 약 $15 \mathrm{~cm}$ 정도만 내시경을 진입 하여도 말단회장에 도달할 정도로 상행결장의 단축이 심했으며, 항문 을 통한 내시경 진입 시에도 항문피부선 상방 $20 \mathrm{~cm}$ 에서 심한 협착 으로 인해 내시경 진입이 불가능하였다. 단축된 대장의 점막은 백색 반흔 및 섬유화가 심하였고 공기 투입만으로도 자발출혈 소견을 보여 오랫동안 지속된 궤양성 대장염으로 판단되었다(Fig. 2). 악성 협착 을 감별하기 위해 협착부위에서 조직검사를 시행하였으나, 악성세포 는 관찰되지 않았다. 추적관찰 중 빈혈이 지속되었으나 종교적 문제 로 수혈을 할 수 없었고 장관의 심한 협착에 대한 치료를 위해 횡행결 장 창냄술을 시행한 지 8개월 째, 전대장절제술과 회장 항문 문합을 시행하였다. 수술장에서 관찰된 소장은 정상소견이었다. 절제된 전대 장의 길이는 $70 \mathrm{~cm}$ 로 심한 단축 소견이 관찰되었다(Fig. 3). 절제된 


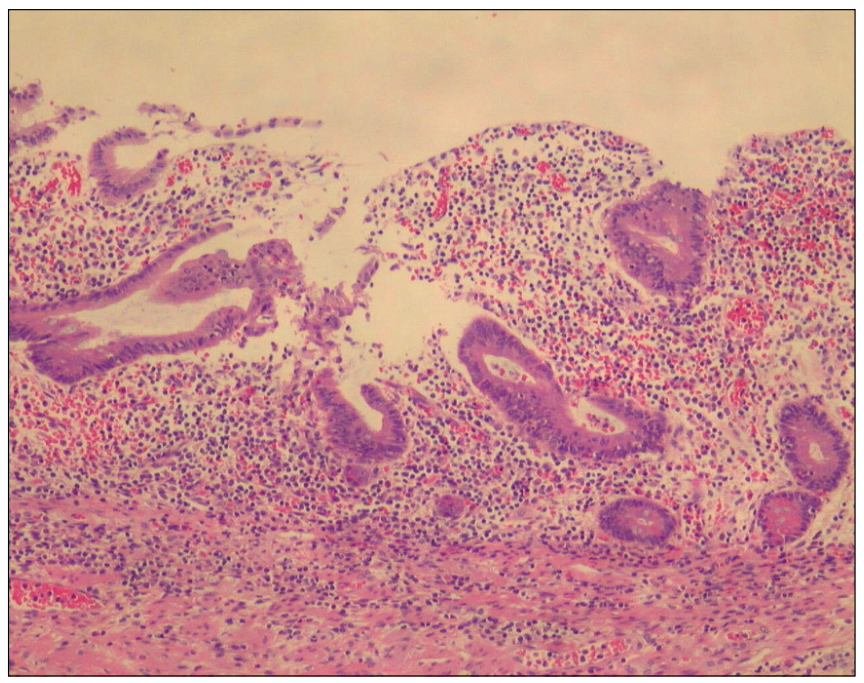

Fig. 4. A histologic section. It shows crypt architectural distortion, cryptitis and paneth cells. These findings are compatible with long standing ulcerative colitis (H\&E stain, $\times 100)$.

조직의 병리 소견에서 광범위한 음와 상피의 호중구 침윤이 관찰되었 고 악성 세포는 관찰되지 않았으며 육아종 소견이 없는 전형적인 궤 양성 대장염 소견을 보였다(Fig. 4).

\section{고 찰}

궤양성 대장염은 전 세계적으로 분포하지만 북미와 북유럽에서 가 장 호발하고 인종별로는 유태인과 코카시안에서 발생이 많으며 동양 인에서는 비교적 드물다. 한국의 궤양성 대장염 유병률은 서구에 비 해선 낮지만 빠르게 증가하고 있다. 최근 20년간 서울의 궤양성 대장 염 발생률에 대한 연구에 따르면 인구 10 만 명당 1.51 명으로 아직 서 구보다 낮지만 빠르게 증가하는 추세를 보인다. 4.5 최근 연구에 따르 면 궤양성 대장염 환자의 장기 생존율은 정상인과 유의한 차이가 없 었는데, ${ }^{6-8}$ 발생률의 증가와 사망률의 감소로 조기진단과 올바른 치 료의 중요성이 점차 강조되고 있다.

저자들은 오랜 기간 동안 적절한 치료를 받지 못한 궤양성 대장염 환자에서 비교적 드문 합병증인 협착과 이로 인해 발생된 누공 및 농 양을 경험하였다. 협착은 유병기간이 긴 궤양성 대장염 환자에서 발 생할 수 있고 주로 직장부터 비장굴곡 사이에서 발생한다. 궤양성 대 장염은 장관의 전층을 침범하는 크론병과는 달리 점막과 점막하층 을 침범하므로 협착이 생기는 원인 또한 크론병과 다르다고 생각되지 만 아직 명확하게 밝혀지진 않았다. 점막근층의 비대와 단축이 원인 일 것이라는 의견이 제시되고 있으며 근섬유모세포와 섬유모세포 성 장인자가 섬유화를 일으킨다는 주장도 있다. ${ }^{2.9}$ 궤양성 대장염 환자의 대장내시경 시행 시 협착을 발견하면 육안적으론 악성과 양성 협착 을 정확히 구분하기 어렵기 때문에 다수의 조직검사가 필요하며 조직 검사에서 악성 소견이 없더라도 대장암을 완전히 배제할 수 없기 때 문에 주의 깊은 추적관찰이 필요하다. 외국의 보고에선 궤양성 대장 염 환자의 협착 중 악성 협착이 약 $25 \%$ 를 차지했고 오랜 이환기간을
보인 궤양성 대장염인 경우, 협착의 위치가 비장만곡부보다 근위부인 경우, 대장폐쇄 증상이 있는 경우 악성 협착일 가능성이 높았다. ${ }^{2}$ 궤 양성대장염 환자의 대장암은 일반 환자의 대장암에 비해 암종의 분 화도가 불량한 경우가 상대적으로 많아 예후가 좋지 않다는 보고가 있고 궤양성 대장염 환자의 대장암 중 협착이 동반된 경우 협착이 없 는 대장암에 비해 예후가 나쁘다는 보고가 있어 주의깊은 관찰이 필 요하며 ${ }^{1}$ 고등급 이형성과 동반된 협착은 대장절제술의 적응증이 된 다. ${ }^{10}$ 이번 증례에서도 대장 협착부위에서 악성 협착 여부를 감별하고 자 여러 개의 조직검사를 시행하였으며, 악성 소견은 관찰되지 않았 고 최종적으로 수술 병변에서도 악성 세포가 관찰되지 않아, 궤양성 대장염에 동반된 양성 협착으로 판명되었다.

누공은 장내에 비정상적 통로가 생긴 것으로 일반적으로는 장관 내의 깊은 궤양이 원인이 되어 형성되며 방광, 질, 피부 등으로 개구하 게 된다. 누공이 작을 경우 항생제 및 내과적 치료가 가능하지만, 누 공의 크기가 크거나 다수의 누공이 발생했을 경우 수술적 치료를 요 하기도 한다. 누공 또한 크론병 환자의 $30 \%$ 정도에서 나타나지만 궤 양성 대장염 환자에선 매우 드문 합병증이다. ${ }^{11}$ 이번 증례의 환자에서 누공은 협착 부위 바로 근위부에서 발생하였으며, 심한 협착에 따른 압력의 증가로 발생하였을 것으로 생각된다.

회장 또는 결장루 수술은 궤양성 대장염 환자가 받는 예정 수술 중 에선 흔하지 않는 수술로, 수술 중 고식적 치료로 복원성 대장직장절 제술을 시행하기 전 합병증을 줄이기 위해 시행할 수 있고 전격성 대 장염, 독성 거대결장 및 심한 출혈 등으로 인해 시행되는 응급 수술 시에는 부분대장 절제술 후 동반되어 시행되기도 한다. 결장루 수술 뒤 전결장절제 및 회장항문 문합으로 전환 시기에 대해서는 여러 의 견이 있지만, 6 개월 이후 수술을 시행하는 것이 골반계 감염 및 패혈 증의 유병률을 낮출 수 있다는 보고가 있다..$^{10,12}$

궤양성 대장염 치료 목표는 증상과 점막의 염증을 호전시켜 관해 를 유도하고, 가능하면 오랜 기간 동안 관해를 유지하여 환자의 삶의 질을 높이는 것이다. 대부분의 환자들에서 치료를 받지 않으면 혈변 과 설사 등의 증상이 지속되므로 적절한 치료를 받아야 한다. 저자들 은 오랜 기간 동안 적절한 치료를 받지 않은 궤양성 대장염 환자에서 협착, 누공, 농양 등의 생명을 위협하는 심각한 합병증을 경험하였다. 최근 우리나라에도 궤양성 대장염 환자의 치료 가이드라인이 제시되 어 $^{13}$ 궤양성 대장염 환자들의 적정 치료에 도움을 주고자 하는 노력이 지속되고 있으며, 향후에도 궤양성 대장염 환자에 있어서 올바른 치 료와 추적관찰의 중요성이 강조되어야 하겠다.

\section{REFERENCES}

1. Feldman M, Friedman LS, Brandt LJ. Sleisenger and Fordtran's gastrointestinal and liver disease pathophysiology/diagnosis/ management. Vol. 2. 9th ed. Philadelphia: WB Saunders, 2010: 1975-2013.

2. Gumaste V, Sachar DB, Greenstein AJ. Benign and malignant colorectal strictures in ulcerative colitis. Gut 1992;33:938-941.

3. Lee JY, Lee SH, Kim SP, et al. A Case of benign colonic stricture treated by therapeutic balloon dilatation in ulcerative colitis. Ko- 
rean J Gastrointest Endosc 2008;37:380-383.

4. Yang SK, Loftus EV Jr, Sandborn WJ. Epidemiology of inflammatory bowel disease in Asia. Inflamm Bowel Dis 2001;7:260-270.

5. Yang SK, Yun S, Kim JH, et al. Epidemiology of inflammatory bowel disease in the Songpa-Kangdong district, Seoul, Korea, 1986-2005: a KASID study. Inflamm Bowel Dis 2008;14:542-549.

6. Loftus EV Jr, Silverstein MD, Sandborn WJ, Tremaine WJ, Harmsen WS, Zinsmeister AR. Ulcerative colitis in Olmsted County, Minnesota, 1940-1993: incidence, prevalence, and survival. Gut 2000;46:336-343.

7. Card T, Hubbard R, Logan RF. Mortality in inflammatory bowel disease: a population-based cohort study. Gastroenterology 2003; 125:1583-1590.

8. Falvey J, Greenwood R, Creed TJ, et al. Mortality in ulcerative colitis-what should we tell our patients? Three year mortality following admission for the treatment of ulcerative colitis: a 6 year retrospective case review. Frontline Gastroenterol 2010;1: 35-41.

9. Rogler G. Pathogenesis of strictures in ulcerative colitis: a field to explore. Digestion 2011;84:10-11.

10. Metcalf AM. Elective and emergent operative management of ulcerative colitis. Surg Clin North Am 2007;87:633-641.

11. Reaves LE 3rd, McDonough FE. Gastrojejunocolic fistula and ulcerative colitis. Report of a case. Am J Dig Dis 1966;11:213-216.

12. Dinnewitzer AJ, Wexner SD, Baig MK, et al. Timing of restorative proctectomy following subtotal colectomy in patients with inflammatory bowel disease. Colorectal Dis 2006;8:278-282.

13. Choi CH, Kim YH, Kim YS, et al.; IBD Study Group of the Korean Association for the Study of Intestinal Diseases. Guidelines for the management of ulcerative colitis. Intest Res 2012;10:1-25. 